- Screw retained restorations are more easily retrieved and maintained.

- Cemented restorations can accommodate more implant positions.

- Screw retained restorations are easier to manage when immediately loading implants.

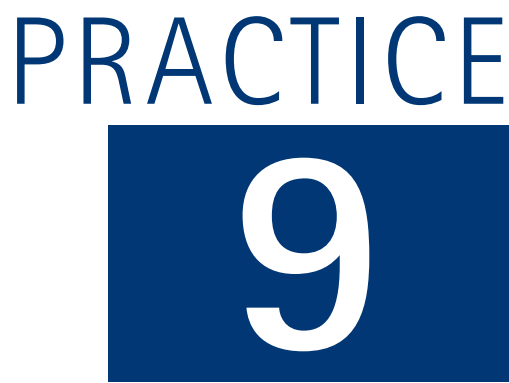

VERIFIABLE

CPD PAPER

\title{
Screw versus cemented implant supported restorations
}

\author{
W. Chee ${ }^{1}$ and S. Jivraj ${ }^{2}$
}

Implant supported restorations can be attached to implants with screws or can be cemented to abutments which are secured to implants with screws. Screw retained implant restorations are the authors' preferred method of securing restorations to implants. This article will be written from this perspective and the advantages and disadvantages of each method of retention will be discussed under the following headings: Aesthetics, Retrievability, Retention, Implant placement, Passivity, Provisionals, Occlusion, Immediate loading, Impression procedures, Long term treatment planning.

\begin{tabular}{|c|}
\hline IMPLANTS \\
\hline 1. Rationale for dental implants \\
\hline $\begin{array}{l}\text { 2. Treatment planning of implants in } \\
\text { posterior quadrants }\end{array}$ \\
\hline $\begin{array}{l}\text { 3. Treatment planning of implants in } \\
\text { the aesthetic zone }\end{array}$ \\
\hline $\begin{array}{l}\text { 4. Surgical guidelines for dental } \\
\text { implant placement }\end{array}$ \\
\hline $\begin{array}{l}\text { 5. Immediate implant placement: } \\
\text { treatment planning and surgical steps } \\
\text { for successful outcomes }\end{array}$ \\
\hline $\begin{array}{l}\text { 6. Treatment planning of the } \\
\text { edentulous maxilla }\end{array}$ \\
\hline $\begin{array}{l}\text { 7. Treatment planning of the } \\
\text { edentulous mandible }\end{array}$ \\
\hline $\begin{array}{l}\text { 8. Impressions techniques for implant } \\
\text { dentistry }\end{array}$ \\
\hline $\begin{array}{l}\text { 9. Screw versus cemented implant } \\
\text { supported restorations }\end{array}$ \\
\hline $\begin{array}{l}\text { 10. Designing abutments for } \\
\text { cement retained implant supported } \\
\text { restorations }\end{array}$ \\
\hline 11. Connecting implants to teeth \\
\hline $\begin{array}{l}\text { 12. Transitioning a patient from teeth } \\
\text { to implants }\end{array}$ \\
\hline $\begin{array}{l}\text { 13. The role of orthodontics in implant } \\
\text { dentistry }\end{array}$ \\
\hline $\begin{array}{l}\text { 14. Interdisciplinary approach to } \\
\text { implant dentistry }\end{array}$ \\
\hline $\begin{array}{l}\text { 15. Factors that affect individual } \\
\text { tooth prognosis and choices in } \\
\text { contemporary treatment planning }\end{array}$ \\
\hline 16. Maintenance and failures \\
\hline
\end{tabular}

\section{AESTHETICS}

Objections to screw retaining restorations to implants due to aesthetics are unfounded; there are situations where screw retention is not possible due to implant position. Obviously in these situations having a screw access in a visible area is unacceptable. When screw access to the implants are in aesthetic areas, the screw access can be re directed at times with use of pre angled abutments or the restoration should be retained with custom abutments and cement retained (Fig. 1). The method of retention to the implant body has little to do with aesthetics; the parameters regarding aesthetics have been discussed in other articles in this series (Figs 2-4). Aesthetics is dependent largely on patient selection, tissue volume, tissue type surrounding the implant

\footnotetext{
${ }^{*}$ Ralph W. and Jean L. Bleak Professor of Restorative Dentistry, Director of Implant Dentistry at the University of Southern California School of Dentistry / Private Prosthodontics Practitioner, Pasadena, California; ${ }^{2}$ Chairman, Section of Fixed Prosthodontics and Operative Dentistry, University of Southern California School of Dentistry / Private Prosthodontics Practitioner, Burbank, California

${ }^{*}$ Correspondence to: Dr Winston Chee, School of Dentistry, Rm. 4374 University Park, University of Southern California, Los Angeles, CA 90089-0641, USA Email:wchee@usc.edu
}

\section{Refereed Paper}

๑ British Dental Journal 2006; 201: 501-507

DOI: $10.1038 /$ sj.bdj.4814157 and implant position (Figs 5-6). The trajectory of the implant will merely determine the method of retention. Cement retention can be used more universally and screw retained restorations can only be used when the trajectory of the implant allows the screw access to be in non-aesthetic areas.

\section{RETRIEVABILITY}

This subject has received the most attention with respect to advantages and disadvantages of retaining implant supported restorations with implants, some authors feel that implant supported restorations should be treated exactly the same way as restorations cemented onto teeth, ie clinicians should not hesitate to destroy otherwise intact restorations to address underlying problems of screw loosening or other maintenance. ${ }^{1}$ Some feel that the problems of screw loosening have been eliminated due to improved implant designs. ${ }^{2}$ Since implants are unlike teeth and with some care restorations can be made to be retrievable, as clinicians we should plan for this possibility. For continued maintenance of patients and for patients who move geographically, the ease of managing these patients is much simpler when there are no doubts about the method of retention and no conjecture is left to what kind of cement is used or what the form of the abutment is under restorations. With improved designs and a better understanding of screw joint mechanics the 
Fig. 1 Intra oral view of provisional restoration replacing maxillary left lateral incisor with labial screw access. The definitive restoration cannot use screw retention and will likely be cemented.

Fig. 2 Pre operative view of patient with missing lateral incisors.

Fig. 3 Radiographs of patient in Figure 2 with implants in place. Note that the left lateral is a screw retained restoration and the right lateral is an abutment for a cemented restoration.

Fig. 4 Post operative view of patient with lateral incisors replaced with implant supported restorations. The patient's left lateral is screw retained and the patient's right lateral is cement retained.

Fig. 5 Intra oral view of a screw retained implant supported restoration replacing the maxillary right central incisor.

Fig. 6 Palatal view of the restoration in Figure 5.

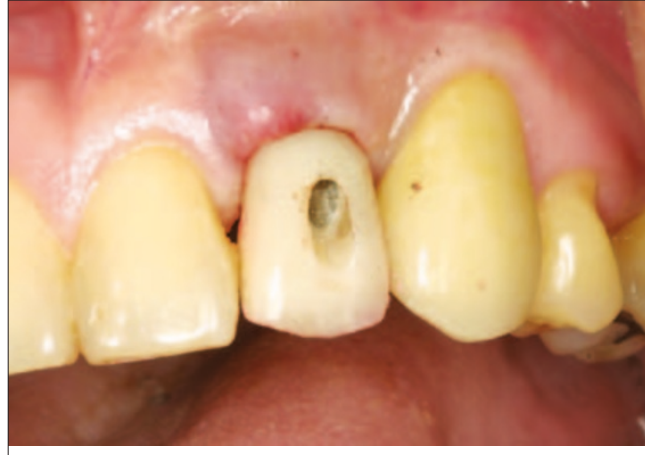

incidence of screw loosening is reduced from earlier reports. ${ }^{3,4}$ However, screw loosening does occur and as the volume of patients treated with implants increases, the number of screw loosening episodes will increase. When abutment screws loosen, cement retained restorations are not always predictably removed from abutments to allow screws to be re-tightened. Numerous methods for retrieval of cemented restorations have been described from guides to access the underlying screws to using screws to displace restorations by pushing against abutments. ${ }^{5-8}$ When restorations cannot be retrieved
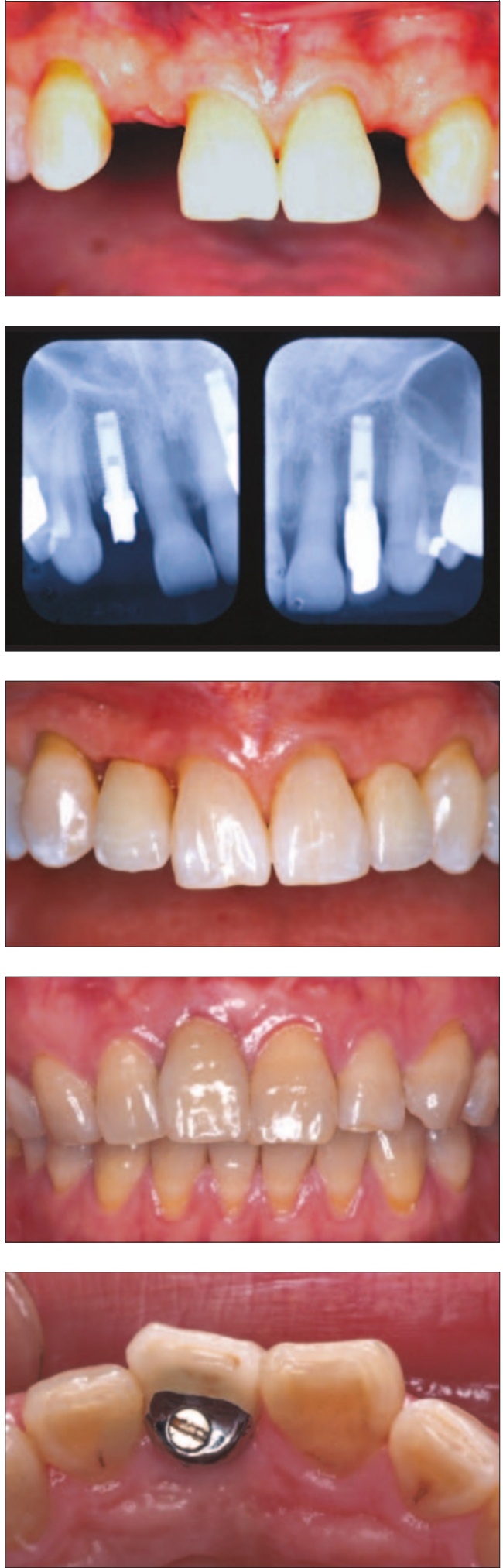

intact, the only option is to cut the restoration off or to access the retaining screw by cutting into the restoration. Both usually render the restoration unserviceable and require that the restorations be re-made. In aesthetic zones it will also require a provisional restoration be placed (Figs 8-14). These clinical examples illustrate consequences of cutting off restorations and cutting through restorations to access abutment screws. Obviously it would be simpler to manage if the restorations were planned for screw retention; in the two examples of posterior teeth there was no rational reason to use cement retained restorations as the screw access holes were in acceptable locations. Additionally, as the complexity of the restoration and the number of units in the restoration increases, the expense to the patient should the restoration be destroyed likewise increases.

\section{RETENTION}

With cement retained restorations, all the principles of retention with conventional fixed prosthodontics will apply and a sufficient abutment size dimension and form are required for adequate retention. However, studies regarding cementing to metal or ceramic substrates with reference to retention are sparse and most clinicians are assuming that cementing to implant components is similar to cementing to tooth structure. In situations when minimal inter occlusal space exists it may not be possible to develop adequate retention to retain restorations to implants with cement. However, screw retained restorations can be secured to implants with as little as $4 \mathrm{~mm}$ of space from the surface of the implant to the opposing occlusion. Figure 15 illustrates a patient presenting with minimal interocclusal space; Figures 16 and 17 show how inter occlusal space was increased with a combination of crown lengthening and shortening of the clinical crown of the maxillary arch. Despite this, minimal interocclusal space was available for implant restorations. The restorations were secured to the implants with screw retention (Figs 18-20).

\section{IMPLANT PLACEMENT}

There is no doubt that placing implants to receive screw retained restorations is more difficult, as the trajectory of the implant is limited by a small area to locate the screw access hole. It is not always possible to achieve this, but if it 
is a goal of implant surgery and care is taken in planning, the outcome of allowing screw retention is often achieved. Planning with the restoration in mind and having well constructed and stable surgical guides is the first prerequisites. ${ }^{11-13}$ Figures 21-23 illustrate an implant restoration where a well made surgical guide was used. Note the ideal spacing and trajectories of implants that allowed proper contours and access holes for the retaining screws to be centered in occlusal surfaces of restorations.

\section{PASSIVITY}

Much has been written in the literature about passivity of the implant framework. It is generally accepted that a passively fitting framework is desirable as it will allow retaining screws to function fully to hold implant components together firmly. In addition a passive framework will not cause strain to the interface between the implant and the bone. It is also known that achieving a totally passive framework is difficult and most of the frameworks that are in place and functioning are not totally passive. Proponents of cement retained restorations are listed as one of the advantages of cement retained restorations. The frameworks are more passive as the abutments are individually retained to the implants by screws and the super structure is cemented over the abutments. The cement space allows for a passive framework - a review of the literature however is equivocal with several articles confirming this and several findings that there is no difference in passivity of either method of retaining restorations to the implants. ${ }^{14-17}$

There are methods of fabricating making frameworks more passive such as EDM (Electric Discharge Machining) or directly luting the framework to abutments seated onto implants intra-orally with composite resin. ${ }^{18-22}$ These techniques can be used to achieve passivity with screw retained prostheses. To eliminate errors from casting and shrinkage of metal, several implant manufacturers are machining titanium frameworks to fit implant analogues on master casts. While this has potential at present, frameworks are not well designed and clinicians are limited to using all components from specific companies. As this technology improves designs will improve and the process will be less restrictive with respect to implants and components used. EDM and milled titanium frameworks only address the errors of casting; they do not address the errors of impression making and distortion of the master cast.

\section{PROVISIONALS}

For ideal aesthetics, a provisional restoration is required to shape and mould the soft tissue. The simplest method is to use a screw retained provisional restoration. Healing caps do not have the proper contours to frame the restoration and are often smaller than the exit profile of a tooth. The screw retained provisional restoration can be placed with ease as the screw can be used to seat the provisional and expand peri implant

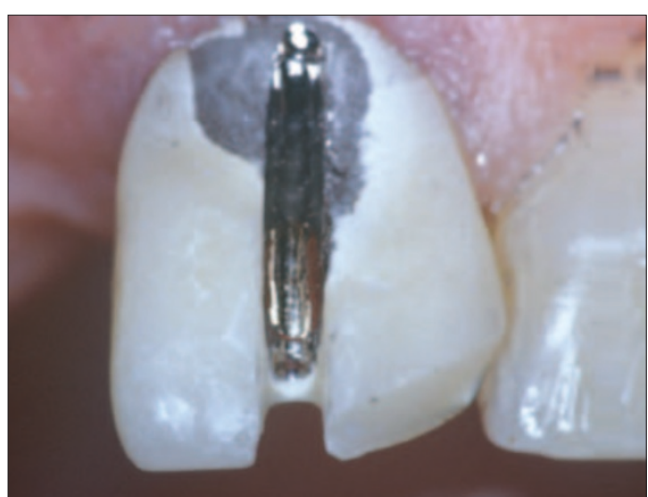

Fig. 7 Cemented implant restoration being cut off to access the retaining screw which has loosened.

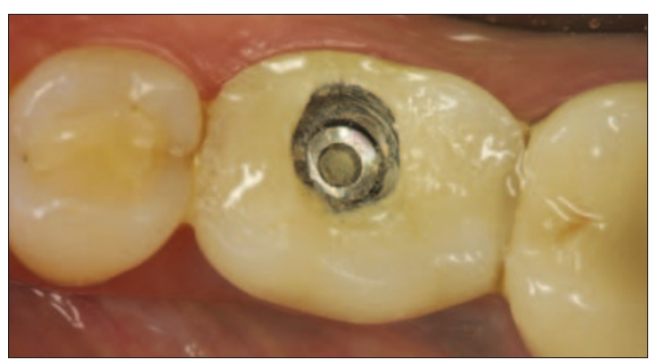

Fig. 8 Intra oral view of a cemented restoration being cut into in order to access the loosened retaining screw.

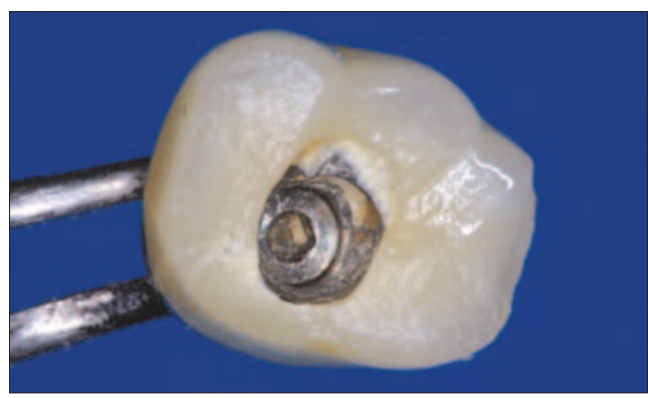

Fig. 9 Restoration in Figure 8

removed.

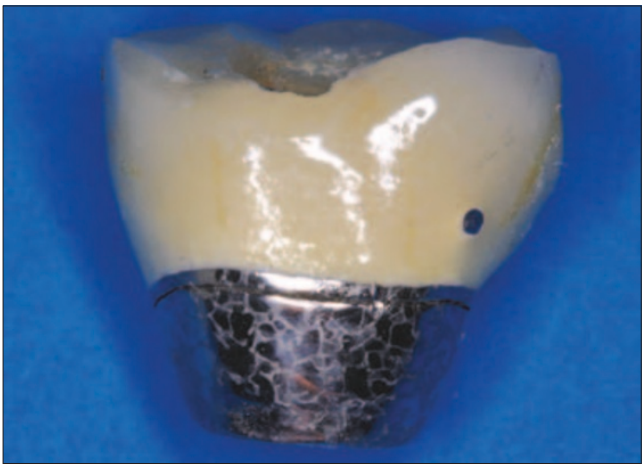

Fig. 10 Lateral view of restoration in Figure 9 showing cement margin.

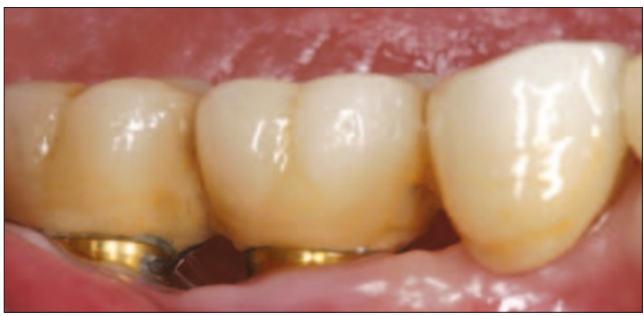

Fig. 11 Splinted fixed partial denture that has abutment screws loosened.

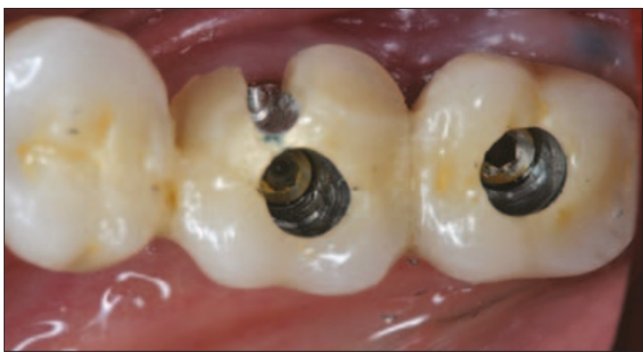

Fig. 12 The restoration in Figure 11 which could not be removed by other means. A buccal cut was attempted before occlusal access was successful in exposing the screws for removal of the restoration. 
Fig. 13 Restoration in Figure 11 removed. Note the cement margin to the abutments.

Fig.14 Extra oral view of the restoration, note the large occlusal access required to engage the abutment screws.

Fig. 15 Intra oral view of patient with limited posterior space for restoration.

Fig. 16 Occlusal reduction performed prior to crown lengthening procedures.

Fig. 17 Post crown lengthening view of Figure 15.

Fig. 18 Implants in place in mandible.
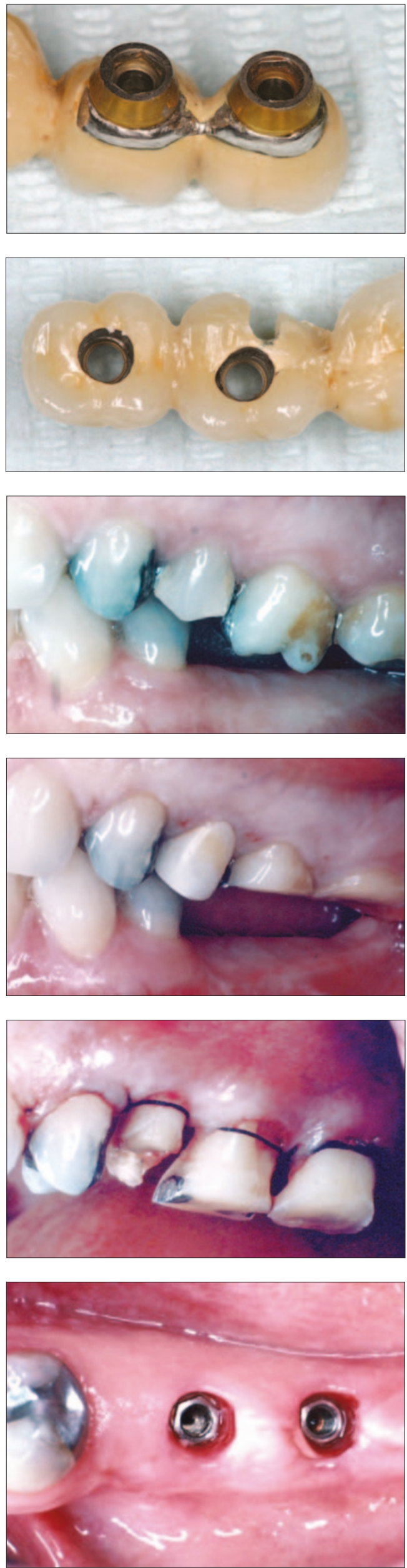

mucosa. ${ }^{23-26}$ Figs $24-28$ are a series of slides which illustrate the advantage of screw retention well. The patient was provisionalised with a pontic attached to the orthodontic wire during implant integration. A provisional cylinder was attached to this pontic with resin (Fig. 24). After modifying the contours of the provisional restoration it is delivered, the tissue is blanched due to the expansion of peri implant soft tissue, at this point a radiograph is taken to confirm seating of the provisional restoration (Figs 25-26). This blanching resolves in about 15 to 20 minutes and after about six weeks the tissue is formed to the desired contours (Fig. 27). Figure 28 is an intra oral view of the completed restoration. As described in another article in the series, with screw retained provisionals, the provisional restoration can be incorporated into the master impression to transfer information about the contours of the restoration to the technician. These procedures are not so easily accomplished with cemented restorations, especially when surgical modifications to the soft tissue are required. It is difficult to manage the bleeding and cement a provisional restoration for ideal tissue health. Figure 29 illustrates this, with the provisional removed retained cement and inflamed tissue is visible in the sulcus.

\section{OCCLUSION}

Some have objected to the screw access occupying occlusal surfaces and obliterating occlusal anatomy. Occlusal access for the retaining screws is determined by the retaining screw diameter. With most of the implant systems this is not a significant problem but when implant systems employ larger screws for larger diameter implants this could obliterate a larger portion of the occlusal surface. ${ }^{27}$ In the authors' experience, no untoward wear or instability to the occlusal contacts occurs with occlusal screw access in the posterior teeth as long as there are contacts on the restoration to the opposing occlusion and the screw access filling material is not required to maintain occlusal contact. With anterior teeth the screw access plays no part in occlusion and there should be no reason to avoid screw access when implant positions allow screw retention.

\section{IMMEDIATELY LOADING IMPLANTS}

When attaching restorations in a surgical field, screw retention has the advantage of not introducing cement into the peri implant areas. When cement margins are deep it is sometimes impossible to remove cement post cementation. $^{28}$ Another advantage of screw retained restorations is that the interface of machined components has been shown to be superior to any cement margin that can be developed. ${ }^{29}$ These two factors together with the fact that with immediately loading implants at the time of extraction, there is often a space between the wall of the extraction and the implant body. are all reasons why screw retention is advantageous with immediate loading. 
Mechanical reasons are also evident for using screw retained restorations when immediately loading implants. Since primary stability is critical to preventing micromotion of the implants, when multiple implants are connected, screw retention allows the most definite and rigid to allow splinting of restorations.

Implant systems which allow only cement retention risk retention of cement which may interfere with healing and integration of implants. Figure 30 illustrates the gap between an implant and the wall of the extraction socket. Figure 31 is an immediately loaded implant which has failed, the reason for failure may not be cement related. However, the cement retention around the abutment is evident.

\section{IMPRESSION PROCEDURES}

As described in another article in the series, screw retained provisional restorations are easily picked up in over impressions allowing transfer of soft tissue contours to the master cast. This facilitates delivery of definitive restorations as exact duplication of soft tissue allows complete seating of definitive restorations without impingement of soft tissues.

\section{LONG TERM TREATMENT PLANNING}

This topic is an extension of retrievability. With the survival of implants in the oral environment, many patients have dentition which succumbs to decay or periodontal disease. If implants have been used to restore missing teeth they can often be used to support pontics if more teeth require extraction. In these situations even the frameworks of the existing implant restorations can be incorporated into the "new' prostheses. Figure 32 illustrates a patient who had implants supporting a restoration in the mandibular anterior area - after some years the adjacent canine and premolar teeth developed dental caries due to the patient being xerostomic from required medications. The two teeth were unrestorable and were extracted. Figure 33 shows a provisional fixed partial denture supported by existing implants which was delivered to replace the two extracted teeth. The definitive restoration was fabricated using the frameworks of the previous existing restorations and soldering on the pontic areas; porcelain was reapplied to complete the restorations. With screw retained restorations, management of these types of situations are simplified compared to cemented restorations and significant cost savings can be realised with use of existing components and the ability to modify them to accommodate future tooth loss.

\section{DISCUSSION}

Though there is no clear advantage of one type of retention over the other, for the reasons described in this article it is the authors' preference to use screw retention as the primary mode when restoring implants. ${ }^{30}$ There are situations when cement retention cannot be avoided and

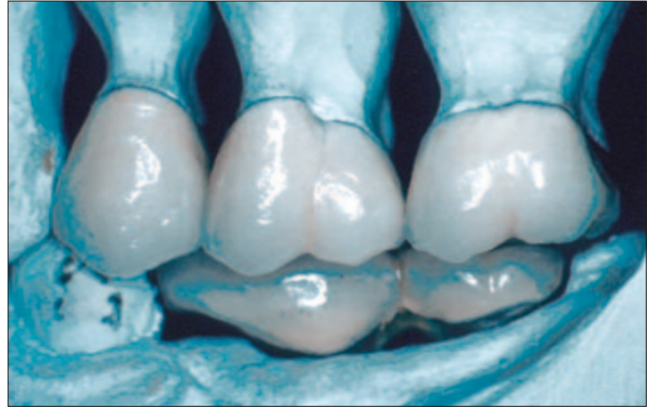

Fig. 19 Restorations developed on master cast.

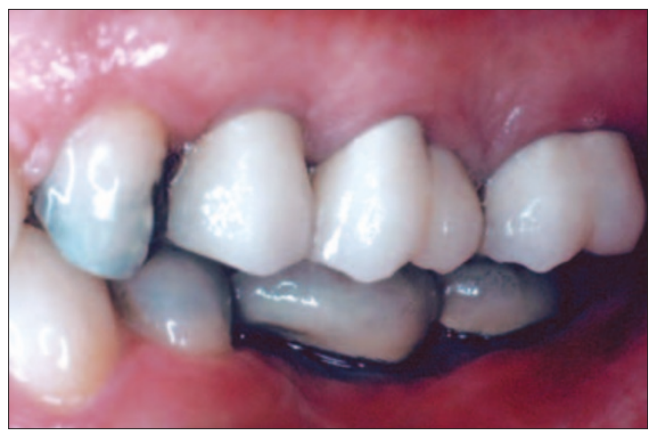

Fig. 20 Intra oral view of restorations, note minimal clinical crown height of mandibular restorations.

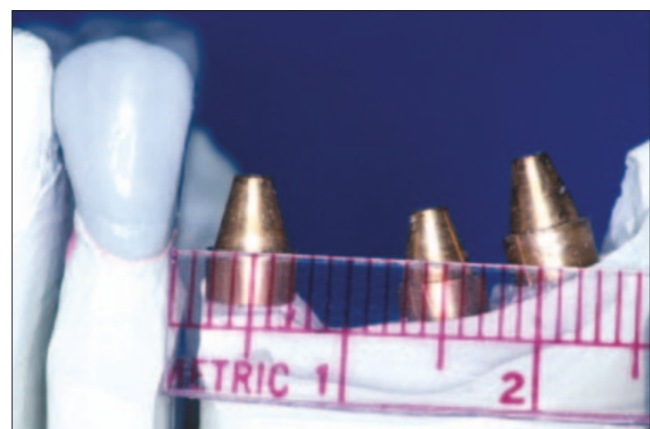

Fig. 21 Ideal spacing for screw retained implant supported restorations.

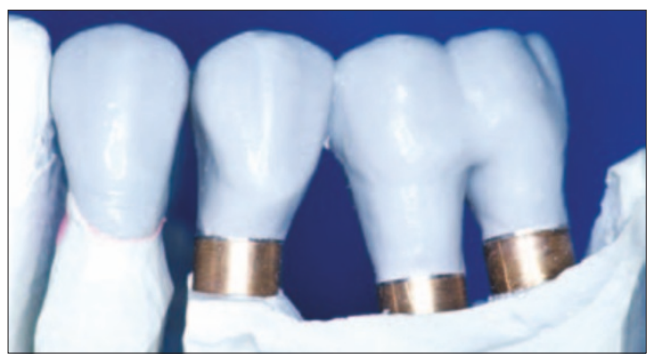

Fig. 22 Normal contours of teeth can be developed with appropriate spacing of implants.

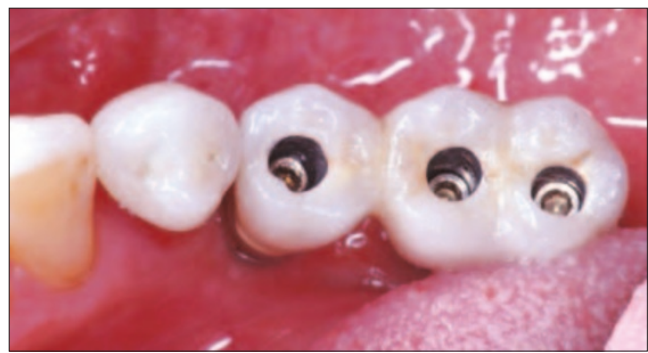

Fig. 23 Intra oral view of restorations in Figure 21 with screw access within the occlusal outline of teeth, this is determined by implant placement.

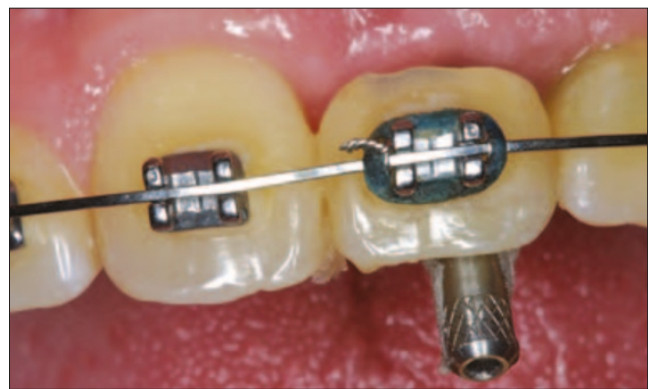

Fig. 24 Intra oral view of temporary cylinder attached to implant behind the pontic which is attached to the orthodontic wire. 
Fig. 25 The pontic is brought to proper contours extra orally and attached to the implant by way of direct screw retention, note the blanching caused by pressure on soft tissues.

Fig. 26 Radiograph of Figure 26 to confirm seating of implant components.

Fig. 27 Soft tissue contours formed by provisional restoration.

Fig. 28 Intra oral view of definitive restoration of patient in Figure 24.

Fig. 29 Intra oral view showing cement retention with cemented provisional restorations.

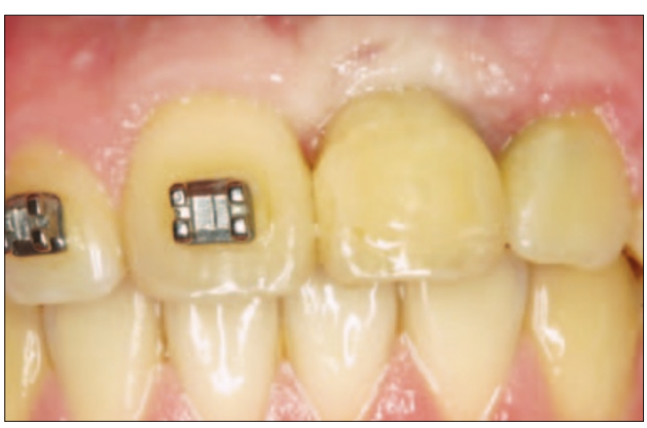

that method is used. Another article will discuss design features of the custom abutments used for cement retention.

1. Misch C E. Screw-retained versus cement-retained implantsupported prostheses. Pract Periodontics Aesthet Dent 1995; 7: 15-18.

2. Chee W, Felton D A, Johnson P F, Sullivan D Y. Cemented versus screw-retained implant prostheses: which is better? Int J Oral Maxillofac Implants 1999; 14: 137-141.

3. Henry PJ, Laney W R, Jemt T et al. Osseointegrated implants for single-tooth replacement: a prospective 5-year multicenter study. Int J Oral Maxillofac Implants 1996; 11: 450-455.

4. Cho S C, Small P N, Elian N, Tarnow D. Screw loosening for standard and wide diameter implants in partially edentulous cases: 3 - to 7-year longitudinal data. Implant Dent 2004; 13: $245-250$.

5. Doerr J. Simplified technique for retrieving cemented implant restorations. J Prosthet Dent 2002; 88: 352-353.

6. Okamoto M, Minagi S. Technique for removing a cemented superstructure from an implant abutment. J Prosthet Dent 2002; 87: 241-242.

7. Gittleman N B. Retrieving cemented telescopic prostheses: technical note. Implant Dent 1996; 5: 91-92.

8. Chee W W, Torbati A, Albouy J P. Retrievable cemented implant restorations. J Prosthodont 1998; 7: 120-125.

9. Garber D A. The aesthetic dental implant: letting restoration be the guide. J Am Dent Assoc 1995; 126: 319-325

10. Salama H, Salama M A, Li T F et al. Treatment planning 2000: an aesthetically oriented revision of the original implant protocol. J Esthet Dent 1997; 9: 55-67.

11. Aalam A A, Reshad M, Chee W W, Nowzari H. Surgical template stabilization with transitional implants in the treatment of the edentulous mandible: a technical note. Int J Oral Maxillofac Implants 2005; 20: 462-465.

12. Shotwell J L, Billy E J, Wang H L, Oh T J. Implant surgical guide fabrication for partially edentulous patients. J Prosthet Dent 2005; 93: 294-297.

13. Meitner SW, Tallents R H. Surgical templates for prosthetically guided implant placement. J Prosthet Dent 2004; 92: 569-574.

14. Pietrabissa R, Gionso L, Quaglini V et al. An in vitro study on compensation of mismatch of screw versus cementretained implant supported fixed prostheses. Clin Oral Implants Res 2000; 11 : 448-457

15. Guichet D L, Caputo A A, Choi H, Sorensen J A. Passivity of fit and marginal opening in screw- or cement-retained implant fixed partial denture designs. Int J Oral Maxillofac Implants 2000; 15: 239-246.

16. Kim W D, Jacobson Z, Nathanson D. In vitro stress analyses of dental implants supporting screw-retained and cementretained prostheses. Implant Dent 1999; 8: 141-151.

17. Heckmann S M, Karl M, Wichmann M G et al. Cement fixation and screw retention: parameters of passive fit. An in vitro study of three-unit implant-supported fixed partial dentures. Clin Oral Implants Res 2004; 15: 466-473.

18. Romero G G, Engelmeier R, Powers J M, Canterbury A A. Accuracy of three corrective techniques for implant bar fabrication. J Prosthet Dent 2000; 84: 602-607.

19. Linehan A D. Windeler A S. Passive fit of implant-retained prosthetic superstructures improved by electric discharge machining. J Prosthodont 1994; 3: 88-95.

20. Aparicio C. A new method for achieving passive fit of an interim restoration supported by Branemark implants: a technical note. Int J Oral Maxillofac Implants 1995; 10: 614-618.

21. Aparicio C. A new method to routinely achieve passive fit of ceramometal prostheses over Branemark osseointegrated implants: a two-year report. Int J Periodontics Restorative Dent 1994; 14: 404-419.

22. Stumpel LJ III, Quon S J. Adhesive abutment cylinder luting. J Prosthet Dent 1993; 69: 398-400.

23. Chee W W. Provisional restorations in soft tissue management around dental implants. Periodonto/ 2000 2001; 27: 139-147.

24. Chee W W, Donovan T. Use of provisional restorations to enhance soft-tissue contours for implant restorations. Compend Contin Educ Dent 1998; 19: 481-486, 488-489.

25. Chee W W, Cho G C, Ha S. Replicating soft tissue contours on working casts for implant restorations. J Prosthodont 1997; 6: 218-220.

26. Neale D, Chee W W. Development of implant soft tissue emergence profile: a technique. J Prosthet Dent 1994 71:364-368. 


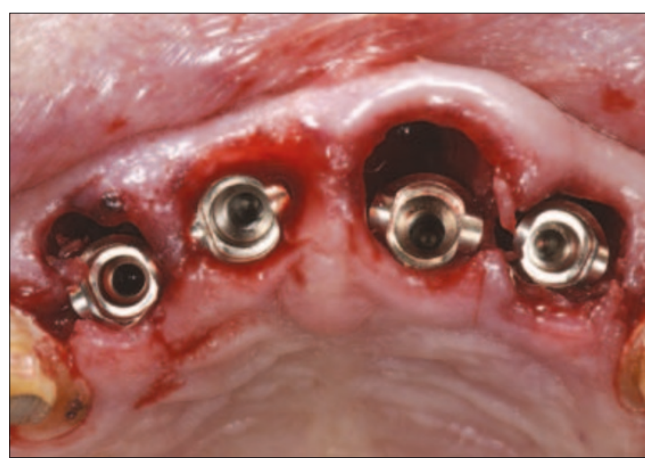

Fig. 30 Implants placed at the time of extraction, note the space between the implant body and the socket wall.

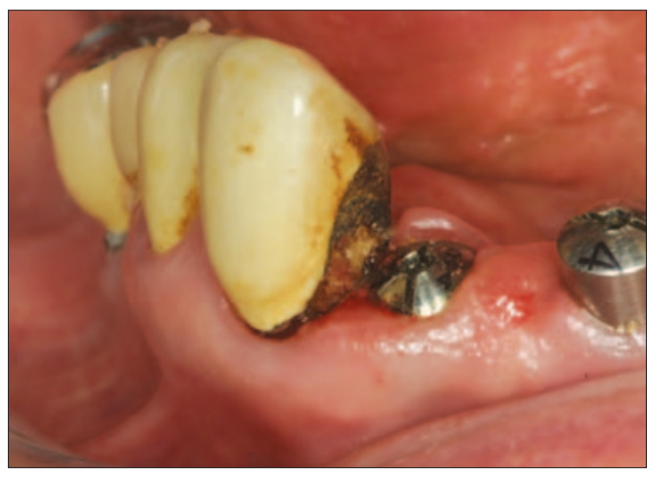

Fig. 32 Recurrent decay around the gingival margins of the mandibular left canine, there is also decay on the mandibular left first premolar.

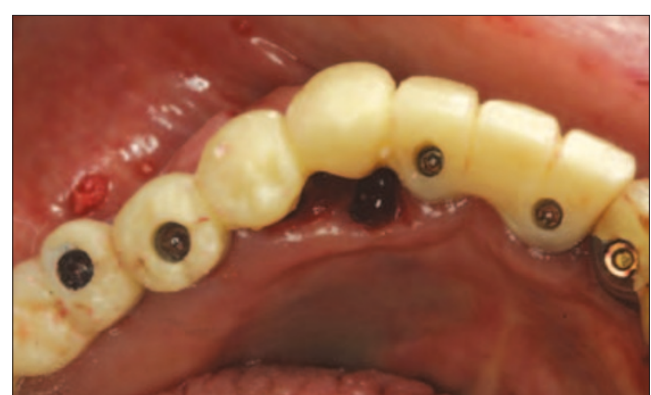

Fig. 34 Screw retained provisional restorations replacing the extracted teeth in place.

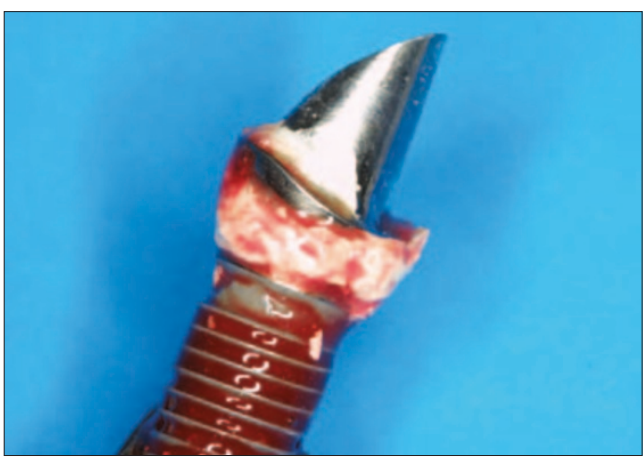

Fig. 31 An implant which has failed and has been removed, note the cement around the abutment which was left.

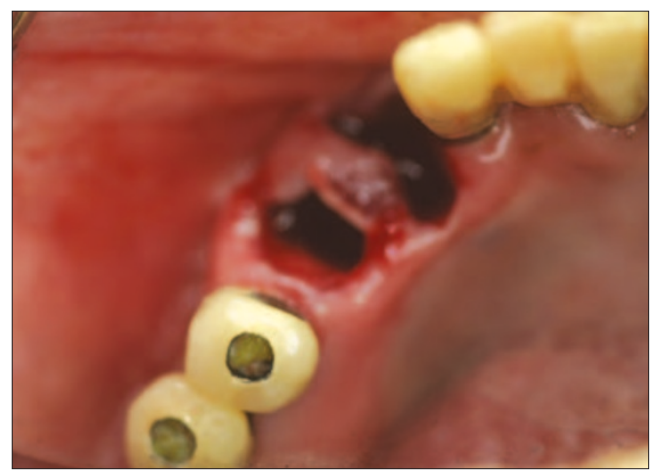

Fig. 33 Occlusal post extraction of teeth in Figure 32, note the implant supported restorations anterior and posterior to extractions.

27. Hebel KS, Gajjar R C. Cement-retained versus screwretained implant restorations: achieving optimal occlusion and aesthetics in implant dentistry. J Prosthet Dent 1997; 77: 28-35.

28. Agar J R, Cameron S M, Hughbanks J C, Parker M H. Cement removal from restorations luted to titanium abutments with simulated subgingival margins. J Prosthet Dent 1997; 78: 43-47.

29. Keith S E, Miller B H, Woody R D, Higginbottom F L. Marginal discrepancy of screw-retained and cemented metal-ceramic crowns on implants abutments. Int J Oral Maxillofac Implants 1999: 14:369-378

30. Michalakis KX, Hirayama H, Garefis P D. Cement-retained versus screw-retained implant restorations: a critical review. Int J Oral Maxillofac Implants 2003; 18: 719-728. 